\title{
Long term follow-up of children with juvenile systemic sclerosis, mixed connective tissue disease and pulmonary disease C Dracou${ }^{1}$, G Syridou*1, S Drakonaki ${ }^{1}$ and G Grigoriadou ${ }^{2}$
}

\author{
Address: ${ }^{1}$ Paediatric Rheumatology Outpatients' Clinic, 2nd Dept. of Paediatrics, NHS and 2Dept. of Paediatric Cardiology, "P. \& A. Kyriakou" \\ Children's Hospital, Athens, Greece \\ * Corresponding author
}

\author{
from I5th Paediatric Rheumatology European Society (PreS) Congress \\ London, UK. 14-17 September 2008 \\ Published: 15 September 2008 \\ Pediatric Rheumatology 2008, 6(Suppl I):P23 I doi:I0.II86/|546-0096-6-SI-P23 I
}

This abstract is available from: http://www.ped-rheum.com/content/6/SI/P23I

(C) 2008 Dracou et al; licensee BioMed Central Ltd.

\section{Background}

Pulmonary disease may be developed in children with juvenile systemic sclerosis (J-SSc) [1] and mixed connective tissue disease. Limited information is available concerning juvenile mixed connective tissue disease ( $\mathrm{J}$ MCTD).

\section{Materials and methods}

To evaluate the prognostic value of pulmonary disease in children with J-SSc and J-MCTD we reviewed the children's records with a diagnosis of J-SSc and J-MCTD since 1989 and a minimum follow-up of 5 years.

\section{Results}

Six (5 female, 1 male) children with J-SSc or J-MCTD were studied. The age at the disease onset ranged from 2-13 yrs. The follow-up duration was $6-18$ yrs (mean 10 yrs). Four children had J-SSc and two had J-MCTD. Three children developed interstitial lung involvement proven by HRCT or chest $\mathrm{x}$-ray. Pulmonary arterial hypertension (PAH) occurred in three children, two with J-SSc and one with JMCTD. One of the two children with J-SSc, $\mathrm{x}$-ray findings of lung involvement and PAH died. In this child the involvement of the respiratory system occurred within the first year of the disease. In the two other children with JSSc or J-MCTD, interstitial lung involvement and PAH subsided after a course of aggressive therapy with corticosteroid, cyclophosphamide and bosentan. Bone marrow transplantation was performed in one child with J-SSc and PAH.

\section{Conclusion}

Severe pulmonary disease may implicate the clinical course of J-SSc and J-MCTD. Pulmonary arterial hypertension indicates very poor prognosis. HRCT may identify those children with interstitial lung involvement who are candidates for aggressive therapy.

\section{References}

I. Martini G, et al: Juvenile Scleroderma Working Group of the Pediatric Rheumatology European Society: Systemic sclerosis in childhood: clinical and immunological features of 153 patients in an international database. Arthritis and Rheum 2006, 54:397I-3978. 